\title{
Chapter 4 \\ Transition Decisions: Intersections of Social Class, Gender and Ethnicity
}

\subsection{Introduction}

The pathways that young people pursue at the end of their educational trajectories reflect both the constraints produced by insecure labour market conditions and the pressure to invest in credentials that will enhance their personal "market value". On the one hand, young people feel the need to prolong their studies beyond their compulsory training (Furlong and Cartmel 1997). On the other hand, they also feel pressured to start working and to gain financial independence from their families. Some combine their studies with part-time work (see Chap. 3), while others choose to leave school altogether. Those who leave the education system without a diploma or with only minimum qualifications are at great risk of exclusion from the labour market (Wolbers et al. 2001). Furthermore, previous studies of youth transitions have shown that leaving education is not necessarily definitive, as young people might return to school or experience cyclical periods of employment, unemployment and training. This has been interpreted as demonstrating the complexity of youth transitions in society today (Wyn and Dwyer 1999). While the literature on youth transitions generally accepts the prolonged and increasingly complex nature of youth transitions (Furlong 2009), we need to scrutinize the factors underlying these processes in order to understand which individuals are able to prolong their transitions (and how), how they cope with complex transitions and what makes for a smooth (or rough) transition.

In this section I scrutinize school-to-work transitions in their full complexity, investigating the prolonged and complex nature of youth transitions. I study transition processes in detail, drawing on the experience of vocational and academic track students when leaving school. First, I will describe the institutional settings and structural conditions in both cities. Thus far, I have only discussed the education system (in terms of the initial stratification point), the labour market structure (in terms of student employment), and the structures for financial support for students 
and the impact that these have on young people's transition decisions. In this section, I will analyze the education systems, this time in terms of their relationship to the labour market, and provide an overview of the labour market structure in both settings. The empirical findings begin with descriptive results from the TIES Survey with regard to transition outcomes. This brief outline is followed by an extended qualitative analysis drawn from the in-depth interviews, which provide crucial insights into the mechanisms behind each transition decision.

The analysis shows that gendered values in the ethnic community and the resources (especially social capital) of young people in relation to their friends and family are significant in shaping both their ('subjective') motivations and their ('objective') conditions. Studying social trajectories in detail reveals how young people negotiate structural constraints when trying to achieve their objectives and how, during their transitions, they build different forms of capital in their trajectories across distinct institutional settings. While focusing on the critical decision made at the so-called 'transition point', this chapter contextualizes that decision in the light of the trajectories of young people discussed in the preceding chapters, to illustrate that transitions do not take place at a single point in time.

\subsection{Institutional Structures}

In this section, I will describe the institutional context of transition in Amsterdam and Strasbourg, concentrating on two structures: the education systems- the opportunities they offer to extend one's education- and labour market conditions when entering the labour market.

\subsubsection{Educational Credentials}

As discussed in Chap. 2, young people's educational trajectories shape both their chances on the labour market and their further study options. Hence, a student's placement in a vocational or an academic trajectory pre-conditions the conditions of their transition outcome. The characteristics and structure of the two trajectories differ between the two settings and offer different opportunities or constraints for those transitioning to the labour market or to further study.

Occupational specificity is an essential characteristic of the educational trajectory for labour market transition. Previous studies have argued that the degree of occupational specificity in education systems plays a vital role in facilitating a smooth incorporation into the labour market (Raffe 2003; Bol and Van De Werfhorst 2013). Occupational specificity is mainly discussed with respect to vocational training, as academic education is perceived to be more scientific and general. However, in higher education, and especially with the growing popularity of tertiary colleges, occupational specificity has also become a significant feature differentiating education systems. 
Dutch vocational training provides occupational skills that are recognized by employers (Mueller and Gangl 2003). This is also true for tertiary education at vocational colleges (HBO) where young people have intensive periods of internship and acquire specific skills in their area of their study. In France, school-based vocational training is more general, with shorter periods of internship (Maurice et al. 1986; Powell et al. 2009). Students have the opportunity to do apprenticeships in upper secondary education and acquire a CAP diploma. However, increasingly, school-based vocational training leading to a BEP diploma is deemed more prestigious as it provides access to professional lyceums and thus is also the gateway to higher education (Duru-Bellat and Kieffer 2008; Powell et al. 2009). In tertiary education, vocational colleges are well established and provide a BTS diploma, though they require only short internship periods compared to Dutch vocational colleges (HBO). An exception is a form of vocational college (BTS en alternance) where young people combine 2 days of training in school with 3 days of work with an employer who is prepared to pay their educational costs and provide them a minimal income (Eckert 2005). Eckert (2005) claims that this form of training has proved very efficient as it usually facilitates a smooth incorporation into the labour market with the same employer.

Previous studies have repeatedly shown that these structures have implications for the outcomes of young people's transitions (Andersen and Van de Werfhorst 2010; Mueller and Gangl 2003). Zdrojewski et al. (2008) argued that vocational graduates in France face a higher risk that employers will judge them on the basis of their diplomas rather than their skills. In the Netherlands, where there is greater skill transparency, those with vocational diplomas benefit from specific skills gained through vocational education, and those who drop out of vocational training without a diploma are very vulnerable when entering the labour market (Iannelli and Raffe 2007; Van der Velden and Wolbers 2006).

In Chap. 2, I showed that a pupil's educational trajectory also determines their further study options. While the pupils in the academic track in both settings can gain direct access to higher education institutions after acquiring a diploma, the higher education institution that they were able to attend depended on their initial trajectory. Increasing credentialism in both the Dutch and French labour markets, means that young graduates from vocational streams also feel that it is necessary to access higher education in order to secure a desirable position. Over the past few decades, it has become increasingly difficult for those leaving the educational system with just qualifications from secondary school to secure a higher occupational level (Wolbers et al. 2001). The availability of student finance and scholarships is another feature of education systems that strongly influences the transition into further study (or not), especially for disadvantaged youth. Financial concerns can create pressure on young people to pass up on further study opportunities or even to drop out of school. As previously discussed, both countries provide financial assistance to students in higher education. As empirical analysis will now show, these arrangements are crucial in shaping young people's decisions to access tertiary education or drop out of education before acquiring a diploma. 


\subsubsection{Labour Market Structure}

Since the beginning of the 1980s, the Dutch labour market has become more flexible as employment protection legislation has been weakened, redundancy procedures relaxed and part-time jobs increased in number (Delsen and Poutsma 2005). Youth unemployment in the Netherlands has been gradually decreasing over the past few years and had fallen to $7.4 \%$ by 2010 . While increased flexibility has had a significant effect on youth unemployment (Remery et al. 2002), it has also resulted in more precarious working conditions, especially among those with lower qualifications (de Vries and Wolbers 2005; Wolbers 2008). Less-qualified young people are now more likely to be offered a temporary contract in their first jobs, compared to graduates of tertiary education, who are more often offered permanent contracts (Wolbers 2008). Those on temporary contracts are more likely to fall back into unemployment, which shows that flexible arrangements often do not provide a 'stepping stone' into stable careers (ibid, p. 98).

France has also made efforts to increase labour market flexibility (Zdrojewski et al. 2008). However, changes in employment protection legislation have reinforced the insider-outsider divide: it is now easier for employers to hire young people, but also to fire them (Zdrojewski et al. 2008). The French government has adopted active labour market measures to reduce youth unemployment among 16-30 year-olds. These include subsidizing public sector employment, promoting training programmes in the private sector and reducing employment costs for private employers. Over this period, there has been a noticeable increase in those working on temporary contracts through employment agencies. As a result, recent studies have shown that the school-to-work transition has become smoother over the last decade. A comparative study by Wolbers (2003) found that young people in the Netherlands and in France are incorporated into the labour market at a similar pace despite differences in their unemployment rates.

Zdrojewski's (2011) analysis of the Generation Survey found that more than $50 \%$ of school leavers in France entered their first job within 3 months of leaving education. However, women and young people from a migrant background took longer to find their first job, and those with lower qualifications also suffered from longer unemployment periods than those with a tertiary qualification. In both countries temporary contracts are more prevalent than before and poorly educated graduates are more likely to work under a temporary contract than those with higher level qualifications. In terms of job stability, those with higher diplomas or vocational degrees are less likely to become unemployed after their first job, than those with lower or general educational qualifications. In both countries, it is more difficult for the descendants of immigrants to access employment. In the Netherlands, the descendants of immigrants from Morocco and Turkey find it more difficult to access high-status jobs than their peers with the same qualifications (Tesser and Dronkers 2007). Young people with immigrant parents are also more likely than the children of native-born parents to fall into unemployment after gaining their first significant job (ibid). Meurs et al. (2005) have shown that young people in France 
with immigrant parents find it more difficult to enter the labour market, even after controlling for qualifications. Brinbaum and Guégnard's (2011) analysis of the 2004 Generation Survey showed that descendants of immigrants from Turkey, the Maghreb and African countries in France, experience higher unemployment and less smooth transitions("access rapide emploi" p. 10) than children of natives and Portuguese immigrants, who fared better. They found a strong correlation between the social class background of these young people's parents and their children's educational and occupational trajectories.

This overview underlines that, in both countries, flexibility measures in the labour market have been instrumental in combating youth unemployment to some extent, but have also led to more precarious employment and careers, especially among those with lower educational attainment (Blossfeld 2008) and with migrant background. Even after controlling for their educational level, the descendants of immigrants seem to face greater disadvantages when entering the labour market (Brinbaum and Guégnard 2011, 2013; Tesser and Dronkers 2007).

The two cities that are the focus of study, Amsterdam and Strasbourg, both have unemployment rates that are lower than the respective national averages. From 2003 to 2006, the unemployment rate in Amsterdam was $7.9 \%$ among men and $6.5 \%$ among women. According to Eurostat (2010) the male unemployment rate in Strasbourg from 1999 to 2002 was $9.4 \%$ and that for women $9.8 \%$. While the unemployment rate was higher in Strasbourg than in Amsterdam, both cities are relatively vibrant economic regions by their national standards. Amsterdam is a typical postindustrial economy, dominated by the service sector, followed by finance, health and care, media, ICT and knowledge (Nell and Rath 2009). This structure is reflected in the occupational choices of the interview respondents. In a recent study, Pasztor (2010) shows that business studies courses have become popular among native-born descendants of immigrants from Turkey as they offer better access to opportunities in the labour market. Services is also the largest sector in Strasbourg, followed by education, health and administration. While, the wider Alsace region is undergoing a transition to a post-industrial economy its manufacturing industry still provides many jobs. Both cities have sizeable populations of economically active immigrants from Turkey and their descendants. In Amsterdam there is entrepreneurship among members of this group, who often run small businesses such as snack bars, restaurants, grocery stores, and dry-cleaners (Kloosterman and Rath 2001). In Strasbourg, in addition to these establishments, the construction sector is a niche for immigrants from Turkey and their descendants, who predominate as both workers and as owners. By contrast, in the Netherlands, the construction sector has remained a protected niche for native-born groups (Rath 2002).

Thus, especially in Strasbourg, immigrant entrepreneurs from Turkey have established businesses that provide a source of employment, though mostly for low status jobs. Such jobs can be vital for descendants of immigrants, especially those who leave school early or with low level credentials. However, from the interviews it became clear that in both settings the descendants of immigrants from Turkey lack valuable contacts to secure positions in larger corporate sectors that require higher qualifications. 


\subsection{Making the Transition}

My analysis of transition processes from school to different activities focuses on four different groups of respondents. The first consists of early school leavers who dropped out of secondary education without a basic diploma. In Amsterdam, this group consists of those who dropped out of education before acquiring a MBO level two (n-2) certificate or HAVO or VWO diplomas. In Strasbourg, this group consists of those who left vocational training without a CAP or BEP diploma or lyceum without a baccalauréat diploma. The second group of respondents left education after successfully finishing vocational post- secondary education. The third group of respondents are those who left education after having received academic post-secondary diplomas such as baccalauréat in France or HAVO/VWO in the Netherlands. The fourth and last group of respondents went on to higher education (from either an academic or a vocational track), some acquiring a diploma, others not.

These four groups were defined on the basis of the institutionally designed trajectories determined by educational streaming. As discussed in Chap. 2, their transitions at the end of their education had largely been pre-conditioned by their initial transitions as a result of tracking. Yet their capital compositions also vary in the educational tracks they follow since differential tracking also instilled them with different types and forms of capital. These resources have an influence on their future trajectories: showing that young people are not necessarily limited by the forms of capital that they inherit from their parents, but also acquire them along their social trajectories in the academic or vocational tracks. In both Amsterdam and Strasbourg the institutional and educational structures influence young people's acquisition of different forms of capital.

\subsubsection{Educational Outcomes of School Leavers in TIES Survey}

Since the implementation of the 2007 Qualification Law, young people in the Netherlands are required to attain at least a basic qualification (startkwalificatie) in order to increase their chances of acquiring stable employment. This entails successfully completing 2 years of post-secondary vocational training (MBO n-2) or obtaining an academic or general-academic secondary school diploma (VWO or HAVO). Those who drop out before attaining these levels are called 'early school leavers'. The proportion of early school leavers has fallen to $9 \%$ in the last decade (CBS 2012), although this figure is higher among the children of immigrants (Kalmijn and Kraaykamp 2003).

In France, recent education reforms aim to ensure that $80 \%$ of students attain at least a baccalauréat, and have set a lyceum diploma as the minimum level. Those who cannot achieve this are encouraged to attain at least a vocational degree (CAP or BEP) (Mellottee et al. 2010). Recent studies in France have shown that young people with a vocational degree are more likely to secure employment than those who drop out of school after college (Duru-Bellat 2000). The chances of finding 
Table 4.1 Highest diploma attained among school leavers Strasbourg

\begin{tabular}{l|l|l|l|l|l|l}
\hline & \multicolumn{3}{|l}{ Strasbourg } \\
\cline { 2 - 8 } & \multicolumn{2}{l}{$\begin{array}{l}\text { Descendants of immigrants } \\
\text { from Turkey in Strasbourg }\end{array}$} & \multicolumn{4}{l}{ Comparison group } \\
\cline { 2 - 8 } & Male & Female & Total & Male & Female & Total \\
\hline $\begin{array}{l}\text { Lower secondary education } \\
\text { (College > out) }\end{array}$ & $25 \%$ & $31 \%$ & $28 \%$ & $4 \%$ & $4 \%$ & $4 \%$ \\
\hline $\begin{array}{l}\text { Vocational post-secondary education } \\
\text { (CAP/BEP > out) }\end{array}$ & $38 \%$ & $27 \%$ & $31 \%$ & $14 \%$ & $10 \%$ & $12 \%$ \\
\hline $\begin{array}{l}\text { Academic post-secondary education } \\
\text { (BAC > out) }\end{array}$ & $18 \%$ & $23 \%$ & $21 \%$ & $24 \%$ & $21 \%$ & $22 \%$ \\
\hline Tertiary education (BTS/Uni. > out) & $19 \%$ & $19 \%$ & $19 \%$ & $58 \%$ & $64 \%$ & $62 \%$ \\
\hline Total (N) & 72 & 104 & 176 & 50 & 67 & 116 \\
\hline
\end{tabular}

Source: TIES Survey 2008

Table 4.2 Highest diploma attained among school leavers in Amsterdam

\begin{tabular}{l|l|l|l|l|l|l}
\hline & \multicolumn{3}{l}{ Amsterdam } \\
\cline { 2 - 8 } & $\begin{array}{l}\text { Descendants of immigrants } \\
\text { from Turkey in Amsterdam }\end{array}$ & \multicolumn{4}{l}{ Comparison group } \\
\cline { 2 - 8 } & Male & Female & Total & Male & Female & Total \\
\hline $\begin{array}{l}\text { Lower secondary education } \\
\text { (VMBO-MBOn1 > out) }\end{array}$ & $44 \%$ & $34 \%$ & $38 \%$ & $10 \%$ & $8 \%$ & $9 \%$ \\
\hline $\begin{array}{l}\text { Vocational post-secondary education } \\
\text { (MBOn2-n3-n4) }\end{array}$ & $25 \%$ & $45 \%$ & $37 \%$ & $22 \%$ & $18 \%$ & $20 \%$ \\
\hline $\begin{array}{l}\text { Academic upper-secondary education } \\
\text { (HAVO/VWO) }\end{array}$ & $6 \%$ & $3 \%$ & $5 \%$ & $9 \%$ & $7 \%$ & $8 \%$ \\
\hline Tertiary education (HBO/Uni. > out) & $24 \%$ & $17 \%$ & $20 \%$ & $59 \%$ & $67 \%$ & $63 \%$ \\
\hline Total (N) & 63 & 86 & 149 & 91 & 92 & 183 \\
\hline Sorce TIES Survey 2008 & & & & & & \\
\hline
\end{tabular}

Source: TIES Survey 2008

employment in France are higher with each additional year of education (ibid). Table 4.1 shows educational attainments among school leavers in Strasbourg among this study's focus and control groups.

The TIES Survey shows that descendants of Turkish migrants, in both Amsterdam and Strasbourg, have lower levels of educational achievement than the comparison group. Table 4.1 illustrates the educational levels of those leaving education in Strasbourg. Twenty-five per cent of male respondents of Turkish origin and $31 \%$ of the females left school without attaining a diploma, whereas this figure was only $4 \%$ among the comparison group. Table 4.2 provides similar data for Amsterdam and reveals similar trends, although here the difference is even more startling. Fortyfour per cent of males and 34\% of females of Turkish origin left school without gaining the minimum qualification, in contrast to the comparison group of which just 9\% left education after VMBO. Early school leavers were highly represented among the qualitative sample. The following section provides detailed biographical interviews, showing show how their pathways led to them becoming early school leavers and how their transitions proceeded thereafter. 
The second large group consists of youngsters who left education with a vocational diploma. Table 4.1 shows that respondents of Turkish origin in Strasbourg more frequently acquire CAP/BEP than those with native-born parents $(31 \% \mathrm{com}$ pared to $12 \%$ ). In Amsterdam, 37\% of respondents of Turkish origin left education with a vocational diploma (MBO) in contrast to $20 \%$ of the control group. In both cities, Turkish second-generation groups are more likely to acquire vocational degrees than their peer group born to native parents. The in-depth interviews highlight how respondents from Amsterdam and Strasbourg in this group pursued different transition pathways and show that the vocational diploma in Amsterdam was of more value in the labour market than CAP/BEP diplomas in France, which, in the majority of cases, led to unskilled work.

The third group consists of survey participants who went on to academic lyceum (although not necessarily completing it). A striking difference between the two countries is the number of youngsters who left education after following an academic track at secondary school. In Strasbourg a substantial number of respondents - both descendants of migrants and the comparison group-did not go on to higher education. This group was much smaller in Amsterdam: $6 \%$ of the male descendants of Turkish migrants and $3 \%$ of the female descendants of Turkish migrants left education compared to $18 \%$ of the males and $23 \%$ of the females with Turkish origin in Strasbourg. This, as I will show later, was related to pupils in Amsterdam having higher expectations about the value of following tertiary education than their peers in Strasbourg. This was exacerbated by the more limited opportunities to combine higher education with work in Strasbourg, which pushed BAC diploma holders out of education and into the labour market.

When we look at those who acquired a diploma from tertiary education we find that descendants of migrants are significantly underrepresented in both cities: 19\% of the second-generation respondents in Amsterdam and 20\% of those in Strasbourg acquired a higher education degree, compared to $62 \%$ and $63 \%$ of the control group in Amsterdam and Strasbourg respectively. Yet, a higher education degree did not always guarantee high returns for descendants of migrants in the labour market, as I will discuss later.

In the next section. I will delve into how transitions in different educational trajectories evolved before and after leaving education.

\subsubsection{Transition Pathways: Insights from the Detailed Respondent Biographies}

\section{Early School Leavers}

The TIES data provides some information on the activities of early school leavers (see Fig. 4.1). This figure should be read with some caution as the sample size for the comparison group in both Amsterdam and Strasbourg was very small (See Tables 4.1 and 4.2, where there are only 4 respondents in total from the comparison group in Strasbourg). 


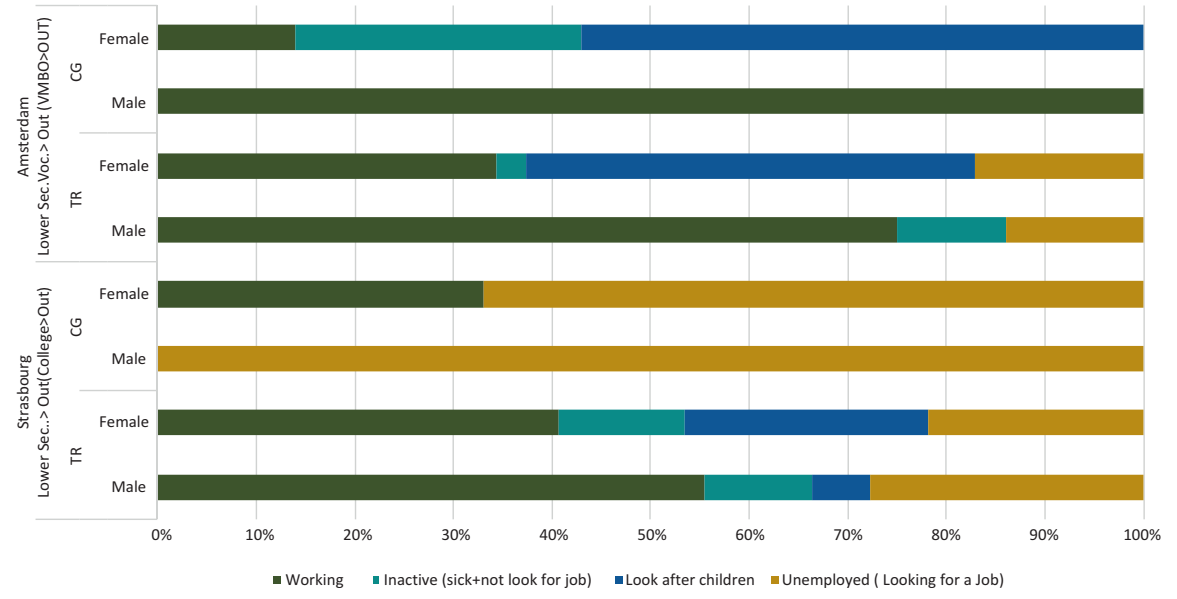

Fig. 4.1 Activity after school among early school leavers. (Source: TIES Survey 2008)

Unemployment levels among early school leavers were quite high in both Strasbourg and Amsterdam, which is not surprising considering that this is the most vulnerable group in the labour market. Figure 4.1 also shows that female respondents in both settings often reported looking after children as their main activity after leaving school. These trends are also discernible within the qualitative data, which I will use to illustrate the social trajectories of youngsters that lead to these outcomes.

The majority of those whom I interviewed in the qualitative fieldwork and who dropped out of school without a minimum qualification fell into low-skilled employment, both in Amsterdam and Strasbourg. Young men mostly opted for maledominated occupations that were physically demanding. In Amsterdam the most popular jobs were as cleaners or baggage handlers at Schiphol airport, or as security guards or taxi drivers. In Strasbourg, low and unskilled jobs were available in the construction sector or assembly lines in manufacturing. The young women in this group either worked in the catering industry or as cleaners, while most of them became homemakers, caring for children. Hence the transitions of early school leavers were gendered (Gaskell 1992) with male respondents under pressure to earn an income (as "breadwinners") and female respondents often getting married young and "looking after the household and children".

Below I will examine the transitional biographies of Şakir, and Defne, a male and a female respondent from Amsterdam. Although their biographies are not necessarily representative, they provide insights into how and why young people of Turkish descent end up leaving school early and how their pathways subsequently evolve. Their trajectories exemplify the gendered nature of transitions and the role of social capital in connecting (or disconnecting) young people with labour market opportunities. This will be followed by two biographies of females of Turkish descent from Strasbourg which, again, show how the respondents left school and how marriage provided a way out of their stagnant transitions. 


\section{Early School Leavers in Amsterdam}

Şakir, a male respondent from Amsterdam, dropped out of school without a vocational post-secondary education (MBO) diploma. His father arrived in the Netherlands in the later 1970s at the age of 18 together with his father and both worked in manufacturing. Şakir was born and raised in Amsterdam. He went to a local primary school, where he scored fairly well on the CITO exam. Despite this, he was advised to take the vocational track, which took him to one of most problematic secondary schools in Amsterdam, where there were issues of pupil criminality. After finishing lower secondary school (VMBO), he decided to do a technical course at a post-secondary vocational school (MBO) as he loved cars and wanted to start his own garage. However, Sakir came into conflict with his class mentor, whom he accused of being a 'racist', as he had suggested that no students with a Turkish background in his course would succeed. The conflict escalated and Şakir was expelled. He subsequently attended other training programmes, but he didn't persevere with them and eventually dropped out of school altogether.

ŞAKIR: First I went to do administration studies. I don't know any Turkish boy who studies administration in order to acquire an occupation; we all go there for the girls. So, you know, I didn't really pay much attention to my studies and soon dropped out. Then I decided to try an $\mathrm{MBO}$ in commerce. I thought I could manage that. But the class was full of Moroccans. And, you know, even since I was little, I have never been able to get along with Moroccans. So, once more, I got involved in a conflict and was eventually expelled. And that was it. I left school.

Even though Şakir acknowledged the importance of studying, and tried various institutions, he lacked a clear goal. In that sense neither Sakir nor any of the other respondents in my study, had a negative reaction towards education as was the case with Paul Willis's (1977) "working-class lads". These youngsters were more like Brown's (1987) “ordinary kids", working-class youngsters with limited resources, who recognized the importance of a diploma for obtaining a decent position on the labour market (Lehmann 2004, 2007). Nevertheless this kind of 'instrumental approach' towards schooling entails the risk that pupils will dropout if they do not perceive school as helping their employment prospects (Longwell-Grice 2003; Macleod 2009). This was the case with Şakir. Furthermore he had started working as a baggage handler at the airport at the age of 16 to pay for his personal expenses as his family had limited resources. So he already had a side-job when he embarked upon his car mechanic training. Each time he dropped out of a course, he could fall back on his student job, working on a full-time basis. Eventually he no longer saw the point in studying as he already had a job and had even been promoted to supervisor. But 2 years down the line, he had become disenchanted with his difficult working conditions, physical strain and lack of prospects. He often had conflicts with his colleagues, whom he defined as either "low-educated old guys or migrants with no other options". Şakir, in contrast, had been born in the Netherlands, spoke Dutch and felt he had more potential. Around this time one of his friends suggested that he find a job as a security guard. At first, he was not sure he could do this as he did not have a basic post-secondary vocational diploma (MBO n-2). His friend reassured him that, as a guard, "you don't do much". He applied and was accepted. 
Şakir expressed mixed feelings about this occupation, saying, "our job is not a job really; you basically do nothing." Yet he also argued that he is "his own boss", and that one actually needs to have social and language skills to be a successful security guard. He talked about how he chats with customers, employees and contributes to creating a pleasant environment in his workplace. At the time of the interview, he was working long hours, 7 days a week, in order to obtain a permanent contract and accrue some savings. He wanted to get married and dreamed of starting his own security company. He mentioned entrepreneurship as a career goal several times during the interview. When asked about returning to school, he stressed that, while this was always an option in the Netherlands, it was one that was closed to him. He suspected that the only drawback of not having a diploma was that it might make it more difficult to get a bank loan when starting his own business. The desire to start one's own company was a common ambition among all respondents, especially those without high hopes of occupational mobility, but also among those with higher qualifications, maybe because they had successful entrepreneurs in their family as role models.

Şakir's case provides an example of losing touch with school and finding an alternative route into the labour market through student jobs and social contacts. Like all male respondents, he felt pressured to earn an income which he did by finding a side-job. While he lacked educational capital as he had left vocational college (MBO) without a minimum diploma, his early exposure to work helped him to develop occupational skills that enabled him to 'market' himself well in interviews and on the shop floor. His connections with friends yielded instrumental social capital which helped him find his current occupation. These skills were developed throughout social trajectories and were not transmitted from his family.

Female respondents who left school without a diploma also ended up in lowskilled jobs. For them, marriage provided an alternative transition route. As Fig. 4.1 showed, looking after children is a common activity among female respondents. The cases of Defne in Amsterdam, and Ayla and Fatmagul in Strasbourg underline the role of marriage as a transition pathway. Defne's case also emphasizes the role that social capital and developing bridging ties with majority group can play in achieving mobility. Defne's mother came to Amsterdam as a child with her parents and married Defne's father, who was from her hometown. The marriage did not last, however, and they divorced just after Defne left lower secondary school (VMBO) at the age of 16. Torn between her parents, Defne decided that the best way to avoid this conflict and establish her independence was to get married. As she put it; "You know, we cannot live on our own or with a boyfriend. So I decided to get married." Since she was not dating anyone at the time, it was an arranged marriage. Her husband was from her parents' hometown in Turkey. She dropped out of school and went to Turkey to get married. However, legislation to discourage overseas marriages (CBS 2012) meant that Defne had to earn enough to support them both in order to bring her husband to the Netherlands. Together with her husband, she did various low-skilled jobs, with her husband mostly working 'black', until they were able to rent their own house and buy furniture. These jobs included working in factories outside Amsterdam, flower shops and as cleaners in the airport. 
Over time, her husband improved his language skills and started his own company with another relative, working as handymen. As soon as his company prospered, Defne took a break from her precarious jobs and became pregnant. After 2 years, her husband was able to acquire a mortgage from the bank to buy their own house. In the new neighbourhood, Defne met a Dutch neighbour, who used to work in a Bank and she told her about a vacancy at a Turkish bank for a desk clerk who could speak both Turkish and Dutch. Defne applied and got the job. She emphasized that she would never have been able to find an equivalent position in a Dutch bank without a full MBO diploma. Here her language capital (bilingual in Turkish and Dutch) and cultural capital as a person of Turkish origin worked in her favour.

The Turkish bank did not see Defne's lack of qualifications as an obstacle, as they were willing to provide on-the-job training. With help from a colleague, Defne received training and learned to handle basic transactions and administrative duties. After her "dirty and heavy jobs", Defne really enjoyed working at the bank. However, the economic crisis led the bank to reduce her full-time contract to a parttime one. Defne was afraid of losing her job and that that she wouldn't be able to get a similar job in a Dutch bank because of her lack of qualifications. This led her to decide to go back to school and start vocational training.

DEFNE: I have made up my mind. I have also told my husband that I cannot go back to cleaning or other jobs like that and he supports me. I want to do an MBO in banking and insurance.

Şakir and Defne's experiences reflect the conditions of young people entering the Dutch labour market, which is credentialist and places a high premium on possession of diplomas. Lacking such educational capital and resources at home, they developed skills through their jobs and social contacts. Şakir relied on his close circle of friends, while Defne's move to a more mixed neighbourhood and contact with a Dutch neighbour facilitated her transition from unskilled to skilled labour (Granovetter 2005). Both of their experiences form an interesting comparison with young people in possession of a vocational diploma in the Netherlands (see next section) and also their counterparts in Strasbourg.

\section{Early School Leavers in Strasbourg}

Despite high number of male early school leavers in Strasbourg, according to TIES Survey analysis (see Table 4.1), all the male respondents I could reach in the field had a minimum vocational diploma (CAP/BEP). Interestingly despite holding minimum qualifications, their labour market experience resembled the Dutch male early school leavers very much as they fell into low-skilled jobs. Their experiences will nevertheless be discussed in the following section. Below I present the stories of two female respondents, whom I could reach in the qualitative field and whose diverse educational ventures failed, leading them to drop out of school and pursue a transition pathway as homemakers. Fatmagul's decision to drop out was related to a structural obstacle: the headscarf ban that was introduced in France in 2004 (Hargreaves 2007). There has been an increase in Islamaphobic rhetoric in politics, 
and especially in the media in both the Netherlands and France, but France institutionalized this hostile discourse in 2004, creating a structural barrier to the education of young women who choose to wear headscarves in French state schools. This headscarf ban, like the one in Turkey, has led to discriminatory practices against women, as only headscarf-wearing Muslim girls are excluded, while Muslim boys not wearing any obvious religious symbols can continue their education without interruption. Fatmagül refused to take off her headscarf and decided to continue her studies from home. Losing contact with her peers made her feel isolated and she became less attentive to her coursework until eventually she quit school. She met a Turkish boy from her parents' village during the summer holidays. After 1 year of long-distance dating online, they got married. Her husband started working with Fatmagül's father on construction sites. Lacking any work experience, Fatmagül ended up stuck at home doing domestic chores while looking for low-skilled work. After her negative experience of being forced to leave school by the headscarf ban, she was not very optimistic about finding a job. At the time of the survey, she was hoping to start work as cleaner in a doctor's office, whom she had heard was not negative about young women wearing headscarves. For Fatmagül, marriage constituted a transition from home to greater independence. Like other young women who had dropped out of education without qualifications, she was actively looking for work, but the options available to her were few and mostly undesirable.

Another interesting case in Strasbourg was that of Ayla, discussed in Chap. 2 when exploring the difficulties of adjusting to the school habitus (Lehmann 2007). Unlike Fatmagül, Ayla was an outstanding pupil. Her teachers at secondary school (collège) recommended that she follow the academic track at the most prestigious lyceum in the centre of Strasbourg. However, after spending most of her education in segregated neighbourhood (quartier) schools, where most of her friends were also from an ethnic-minority background, Ayla could not adjust to the habitus of the new school where most of the students were upper-middle class, ambitious and very competitive. Unable to relate to or form connections with her classmates and teachers, Ayla's grades began to fall and she failed her oral baccalauréat exam. She then went on a summer vacation in Turkey, where she fell in love with a Turkish boy. He was studying in a Turkish University and they kept in touch online. When she returned to France, she decided to enrol once more to prepare for the baccalauréat exam. She was placed in a class with new students and, as the eldest pupil, she felt even more out of place. Shortly afterwards, she decided to drop out altogether, get married and move to Turkey. Her parents were disappointed but eventually agreed to her decision. She got married at the age of 18 in Turkey, where she stayed for around 1 year. Ayla acknowledges that she would have tried harder at school if she hadn't met her husband, but also stresses that she was disappointed and eager to leave.

AYLA: Let me say it this way; around the time I felt most detached from school, I met him. It just coincided. It was a when time I was getting discouraged from studying and my grades were falling. When we met I became even more confused. We started chatting and I just didn't care anymore. Maybe if I hadn't met him, I would have pulled myself together, but, yeah, this was the way it was supposed to be. I was only seventeen. 
Eventually the couple returned to France. Ayla and her husband had two children in the space of 3 years, and she stayed home to take care of them. Ayla's husband found a job with the help of her family, and also learnt some French. Ayla is planning on going back to school and she has modified her dream of being a doctor to getting a chemistry degree and becoming a teacher. She says her husband strongly supports her decision, and she has already signed up to take her baccalauréat exam.

These social trajectories of descendants of Turkish migrants who dropped out of education without a minimum diploma are revealing. First of all, none of the respondents displayed reactionary attitudes toward education. On the contrary, they all acknowledged the value of a diploma and tried to attend and do well at school. They experienced obstacles on the micro, meso and macro level. On the individual level, they lacked clear career pathways (Şakir). On the meso level they had problems at home (Defne), they had conflicts with teachers or peers (Şakir) or difficulty adjusting to the school habitus as in the case of Ayla, while on the macro level, structural barriers such as the headscarf ban (Fatmagul) led to them leaving education without a diploma. Leaving education without a diploma meant that most of them had to resort to low-skilled jobs, through which they tried to develop forms of capital to help them pursue their careers. These profiles also highlight a lack of clarity about when exactly transitions begin and end. While returning to school was not an option for Şakir, Defne or Fatmagül, Ayla still held hopes that this may improve her chances in the labour market. The gendered values held within the Turkish ethnic community has been another important aspect of their transitions. For many young women, marriage emerged as a transition pathway providing a way out of their 'stuck' transitions. Sometimes it offered a way to leave the parental home, while at others it was an alternative to school or the labour market.

\section{Post-secondary Vocational Graduates}

Figure 4.2 shows the post-school activities among those who left education with a post-secondary vocational diploma. Once more, caution should be taken with interpreting the data for the comparison group (especially in Strasbourg) as the sample was very small. We see different activity rates in both settings, where second- generation Turkish males in Strasbourg had higher activity rates and lower unemployment rates compared to those in Amsterdam. Once again looking after children is a common activity among the female respondents (also in the comparison group), although more so in Amsterdam than in Strasbourg.

The insights from the in-depth interviews do not provide much explanation for these trends. What is clear from the qualitative interviews is that most graduates of vocational training in Amsterdam found jobs that were related to their study and that matched their skills. In Strasbourg, most of the same group did low-skilled jobs, despite having post-secondary vocational qualifications. The higher unemployment rates in Amsterdam could be due to the fact that it may be ("more") difficult for second-generation males and females in Amsterdam to find employment in the area of their studies, compared to the second generation in Strasbourg, whom often had 


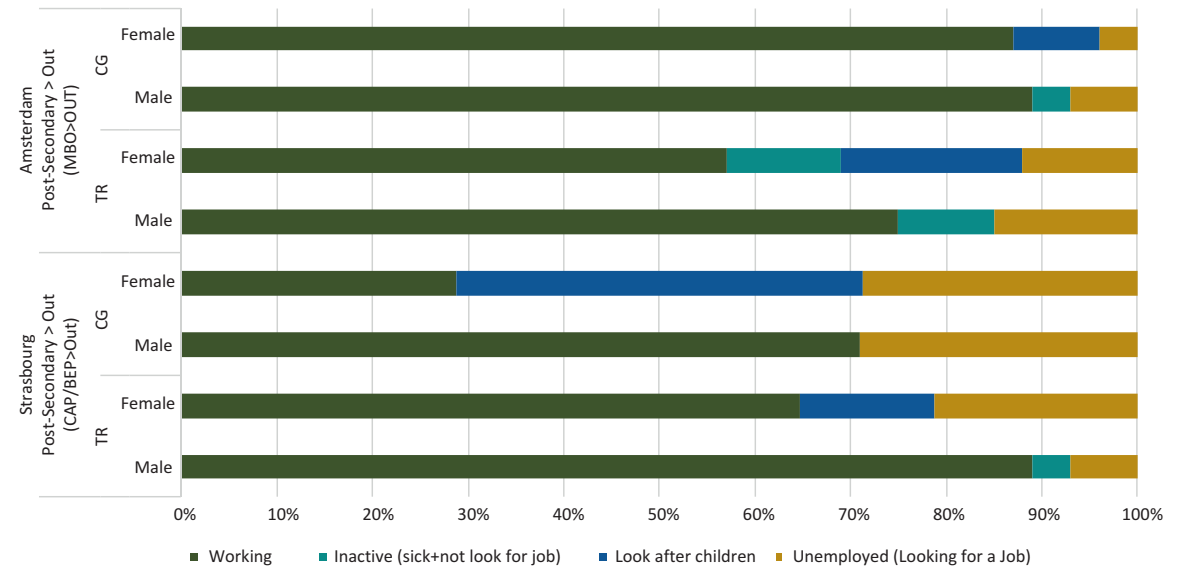

Fig. 4.2 Activity after school among vocational diploma holders. (Source: TIES Survey 2008)

to resort to unskilled jobs. The Dutch vocational training system provides schoolbased training supplemented by extended periods of internship that enable young people to gain occupation-specific skills. This internship experience marks the main difference between the settings with regard to youth transitions. Students in Amsterdam develop an understanding of the tasks they will perform in the workplace and the skills required by their jobs during their internships. Failure to find a good internship, where they can learn relevant skills, may form an obstacle to finding a job later on. My interviewees in Amsterdam often voiced concerns about finding appropriate internships as this could impact on their future employment prospects, a concern which was absent in Strasbourg.

Post-secondary Vocational Education Graduates in Amsterdam

Most vocational track respondents whom I interviewed in Amsterdam had trained for jobs in the service sector, such as banking and insurance, administration, IT or business. Hardly any of their parents were able to provide assistance or social capital in these sectors. As a result, most of them had to rely on the forms of capital, especially job-related information and social capital that they accrued through their internships and student jobs. Their internship experiences also provided them with information that sometimes led them to modify their occupational pathways. For example, Kuzey chose to study accounting and management at a post-secondary vocational training college (MBO), but after his internship, decided that he didn't want to spend the rest of his life making calculations on a computer. As a result, he switched to training as a security guard, as this allowed him to work outdoors with more flexible working conditions. He entered the labour market straight after completing his course. 
Gülden (aged 25 at the time of the interview) is the seventh child of an immigrant family from Turkey living in Amsterdam. Her profile shows how a lack of resources at home can be compensated for by vocational training (educational capital) and internship experience (cultural and social capital significant for attaining a job). The youngest in the family, she was the only sibling born in the Netherlands. Her father had retired from his manufacturing job and her mother had never been employed. Neither spoke good Dutch. Gülden was advised to choose the vocational track, and pursued senior secondary vocational training in banking and insurance, taking two 6-month internships. Through her studies and internship, she developed both social and cultural capital that were relevant to her future occupation. She built job-related skills, while also learning about time management, relations with colleagues and managing an agenda, skills that she had not come into contact with prior to her internship. In terms of social capital, her second employer, a corporate bank, offered her a job as a bank clerk while she was still studying. Two weeks after graduation, she started working there full-time. Although Gülden worked at the bank for 4 years she was never offered a permanent contract. When the economic crisis hit, she was made redundant, together with hundreds of other (low-ranking) employees. Before she left, her bank recommended her to a corporate Turkish Bank based in Amsterdam. She has now been employed there for over 2 years. She was even happier with her second job, as she gained new skills and had a higher position as her knowledge of the Turkish language and culture were crucial resources. Moreover her knowledge of the Dutch system and language were also significant forms of capital since most employees in the bank were recent Turkish migrants, who did not speak Dutch and were not familiar with the Netherlands. At the time of the interview, she still did not have a permanent contract, but was optimistic about getting one. Gülden was the highest-qualified person in her family, as her older brothers and sisters had little education. She never considered prolonging her studies into higher education.

INTERVIEWER: What do you think about labour market opportunities in the Netherlands?

GÜLDEN: Let me tell you this. I studied MBO, but I can find a job much more easily than an $\mathrm{HBO}$ graduate. Really! Because [HBO graduates] are more expensive. Employers have to pay them more to do the same job. That's why MBO graduates can find a job more quickly.

During this period, Gülden married another first-generation migrant from her parents' hometown in Turkey. He had left university without a diploma and is dissatisfied with the opportunities available to him in Amsterdam. The couple were still living with Gülden's family, waiting for social housing and her husband was working through contacts provided by her family. For Gülden, marriage simply accompanied her pathway rather than creating an alternative or a way out but her marriage decision was also comparable to rest of the women in my sample.

Most of male and female respondents in the vocational track married young and chose partners from the Turkish community, who were either from the first or second generation. Marriage emerged as a transition pathway while they were mostly following institutionally informed transitions from education to work.

The interviews with vocational students in Amsterdam underlined the importance of the internship experience in which they acknowledged the importance of vocational skills in facilitating their transitions. The majority of respondents from 
the vocational track in Amsterdam found jobs that were related to their studies and many through their internships or contacts they made during their internships. By contrast, there were no instances of this among my respondents from post-secondary vocational education in Strasbourg.

\section{Post-secondary Vocational Education Graduates in Strasbourg}

Vocational educational in France is less occupational-skill-specific than in the Netherlands (Powell et al. 2009). Yet, the skills required for jobs are usually gained in the work place and, therefore there is not a clear link between educational credentials and occupation (Hannan et al. 1997). In France, most respondents with vocational diplomas found that their qualifications did not pave the way to suitable employment and, instead, they ended up in a range of low-skilled jobs. This is perhaps partly due to the increase in educational credentialism in France, which places great emphasis on encouraging young people to get a BAC, which means that vocational qualifications have become devalued (Duru-Bellat and Kieffer 2008). Many of the respondents said that the CAP/BEP vocational diplomas had become increasingly redundant over the past 10 years. This change was also voiced by older and younger respondents; older respondents saying when they graduated BEP/CAP diplomas counted more compared to younger respondents claiming the opposite.

Most male vocational students in Strasbourg had learned manual trades, such as auto mechanics, maintenance work, plumbing and technical repairs, while the females studied accountancy or administration, and one even studied sewing. When they entered the labour market, most male respondents started working on assembly lines, construction sites or as vendors in the market place. These were the kind of jobs that they could easily access via family members or by registering at employment agencies (interim). In contrast, those who left school with a baccalauréat worked in stores as sales assistants, bus drivers or did other jobs, mostly in the service sector. Many male respondents did not consider further training as a viable option as they wanted to start working and earning an income as soon as possible. These students had started working in family businesses, such as market stalls, bazaars or construction sites.

The case of Selahattin exemplifies the financial pressures felt by most male descendants of migrants that prompted them to leave education as soon as they learned a trade in a vocational programme (even though they did not use this trade in the labour market). He is the youngest child of a migrant family from Turkey, the only member of the family born in France, his other siblings had low-skilled jobs. Obtaining his BEP diploma in plumbing made him the highest qualified person in his family. Even though Selahattin's grades were above average, he never considered higher education as he wanted to earn an income, get his driving license, buy a car and become financially independent. He therefore left education after gaining his vocational diploma (BEP). Yet despite having a vocational diploma ("trade") Selahattin did not find work as a plumber, but became a street vendor in a market stall, together with his brother. After 4 years in the market, he concluded that street stalls were no longer sufficiently profitable, so they closed their stall and Selahattin 
started working on assembly lines. He found jobs through employment agencies (interim), and changed employment constantly, never receiving a permanent contract. Some time before our interview he was injured at work and had to have an operation on his spine, which was followed by a year of sick leave. He was planning on returning to work in the factory. His ambition was to acquire a stable labour market position, get married and start a family. Selahattin was 29 at the time of the interview, and had been working since he left school at age 17. Having a vocational diploma had clearly done little to help Selahattin find a job related to his course or secure a stable position on the labour market. Instead he moved from one physically demanding job to the other. His case was very similar to my other Turkish respondents from Strasbourg with the same level of qualifications who had found employment but never achieved stable careers that were related to their vocational diplomas.

\section{Post-secondary Academic Education Graduates}

One striking difference between Amsterdam and Strasbourg is that some of my interviewees in Strasbourg left school after receiving an academic tertiary (baccalauréat). Whereas in Amsterdam such pathways are extremely rare. This was also evident in the TIES survey which showed that dropout rates were much lower among academic and general track pupils in Amsterdam than in Strasbourg. According to Table 4.1,21\% of the respondents with Turkish immigrant parents and $22 \%$ of the respondents with French parents left education with a bac diploma. In contrast Table 4.2 shows that $5 \%$ of the descendants of Turkish migrants and $8 \%$ of the comparison group left education after academic upper secondary education (HAVO/VWO).

Hence in this section I will provide a case study from Strasbourg with the aim to exemplify the profiles dropping out of baccalauréat. Although an academic diploma was clearly more prestigious than a vocational qualification such as BEP/CAP, my interviewees in France disputed the advantages provided by a baccalauréat, saying that a baccalauréat "means nothing by itself", as it only provided evidence of a high level of general education but had no professional orientation. However having a baccalauréat did not motivate them to pursue higher education: partly because they were not convinced that a higher education diploma would really guarantee competitive advantage in the labour market and partly because many of them felt under pressure to earn a living and felt unwilling or unable to postpone their labour market entry for 4 years.

Engin, from Strasbourg, left education with a bac tech. His mother had come to Strasbourg at the age of 12, and received some language training. She spoke good French and worked in the European Parliament as a cleaner. His father joined her after their marriage and worked as a butcher. The family lived in the suburbs of Strasbourg, where the schools had a bad reputation so Engin's parents sent him to a private school outside the neighbourhood. Yet after getting his technical baccalauréat diploma, Engin did not want to go to university, arguing that it would not give 
him any occupational skills or experience relevant to the labour market. Instead, he tried to enrol in a tertiary vocational school which offers long periods of internship experience (BTS en alternance).

ENGIN: I have never wanted to go to university because you can't gain any experience there. Then there is BTS. There is one public one. I didn't want that either because there you only go to school. Again, you don't work, you don't make money or gain any experience. I needed to make money, you know and I also wanted to work and gain some experience. That's why I tried BTS en alternance. I sent my CV to nearly 100 employers; people we know, acquaintances, family, friends. I also looked on the Internet; [I found] nothing. Then I looked for a job and started working at Zara.

Unlike university or other forms of vocational tertiary training, BTS en alternance combines 2 days of in-school training with 3 days of working for an employer. In many ways it is similar to the dual study programmes in Amsterdam (which are available both in post-secondary vocational training and in the tertiary vocational track). Most students who access this training develop relevant job experience that is related to their studies and end up getting offered a job with the same employer, thereby experiencing a smooth labour market entry. However, this new form of BTS is highly selective. Students need to find an employer who will finance their studies in return for a lower wage, equivalent to the official minimum income (Smig). Engin tried hard to access one but did not succeed. At the time of the interview, his plan was to save money and start his own business.

In Strasbourg, uncertainty about the usefulness of tertiary education diplomas and pressure to earn an income (especially among males) contributed to young people's decisions to drop out of education after academic post-secondary education. There were no instances of this among my respondents in Amsterdam, where respondents were reassured about the returns of higher education as we will see below.

\section{Higher Education Graduates}

When we look at activity levels of those who left education with a higher education diploma; we see higher unemployment rates among descendants of migrants from Turkey than among the comparison group, especially in Amsterdam. General statistics show that, since 2003, second generation migrants in the Netherlands with higher vocational training suffered higher unemployment rates than their Dutch peers (Hoger Onderwijs Bureau 2015) (Fig. 4.3).

In the coming sections, I will concentrate on the qualitative interviews with respondents who been through higher education. These interviews help explain the mechanisms behind the transition processes of highly-educated descendants of migrants. The respondents' profiles are utilized to show that prolonging one's educational trajectory into higher education is not a straightforward activity, but one that requires both resources and support from one's family and significant others. 


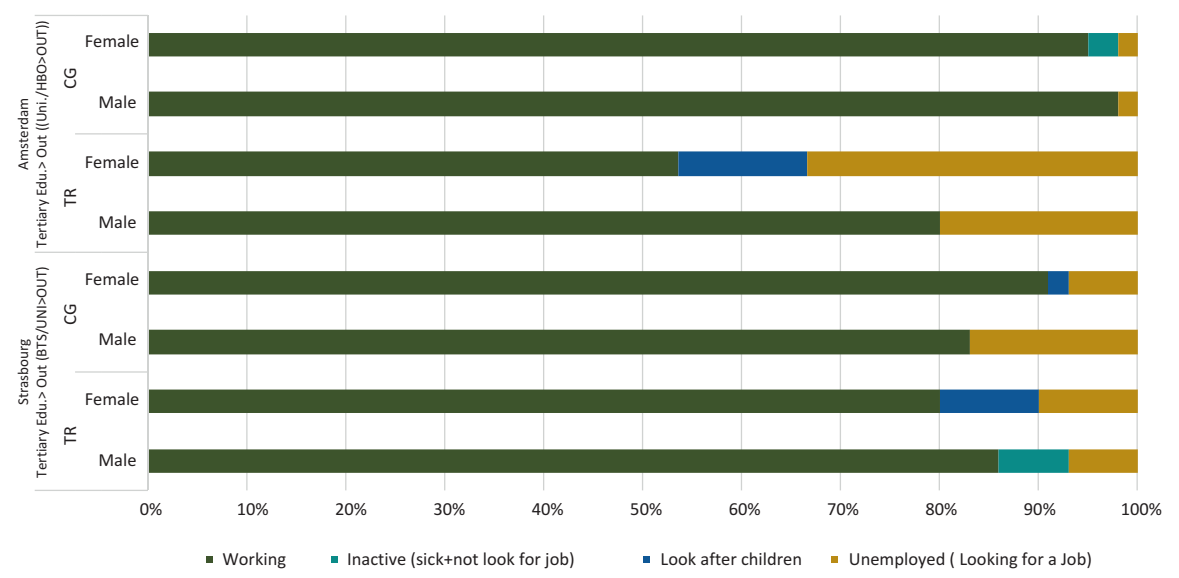

Fig. 4.3 Activity after school among higher education diploma holders. (Source: TIES Survey 2008)

Some institutional structures facilitate the prolongation process; the efforts required to extend one's schooling into tertiary education is not the same for academic and vocational track students and there were differences between Amsterdam and Strasbourg. Furthermore, providing detailed transition experiences of well-educated descendants of migrants, helps to shed a light on the reasons for the high unemployment rates observed within the group.

Academic Track Students' Experiences of Higher Education and Beyond: Prolongation Practice

When accessing higher education, academic track pupils in Amsterdam experienced a rather smooth decision-making process. Through early stratification, most respondents had been prepared and conditioned to enter their assigned higher education track without further consideration (HAVO students go to HBO and VWO students go to University) and they were confident about the returns of higher education. However, as discussed in the previous section, the lack of transparency regarding the benefits of higher education in France meant that accessing higher education was not so straightforward for some academic track students in Strasbourg. Nevertheless, a considerable number of baccalauréat holders did go onto universities or higher vocational institutions.

In order to prolong their transition young people depend on support provided by their families. As discussed in Chap. 1, parents who had arrived earlier in the host countries and had been able to develop language skills and cultural capital concerning the education system were better placed to be supportive of their children's schooling. 
Bulut from Amsterdam and Zeynep from Strasbourg relied on the support provided by their families to extend their educational careers. After graduating from vocational college (HBO) with a degree in business administration, Bulut did a 2-year MA degree in finance. She received full support from her parents, who not only covered the cost of her studies but also provided an ideal working environment, in which she had her own room and meals were organized according to her study schedule. Both of Bulut's parents had arrived in the Netherlands at the age of 12 and attended Dutch schools. Aware of increasing credentialism, they used all the means at their disposal to support Bulut. After acquiring her HBO degree, Bulut enrolled in a university. First she had to do a pre-Masters year and take additional courses in philosophy, maths and English. English was the most difficult subject for her, and she had to pay for private classes. In the end, she successfully completed the programme and acquired her MA degree.

One feature that emerges from Bulut's biography is that attending higher education allowed her to enlarge her circle of friends and social contacts. Her internship experiences, in particular, gave her the opportunity to develop social capital that was crucial for her (future) youth transitions. Throughout the interview she emphasized that she had also benefited greatly from her internship experience during her HBO and her interactions with her classmates. During her vocational degree course, Bulut did an internship with a prestigious Dutch private bank, a position she gained through a 'well-off' classmate whose father was a well-respected dentist. She later obtained a part-time position at ABN-AMRO during her MA studies, and thinks that her previous internship experience was instrumental in this:

INTERVIEWER: What do you think about your work experience as a student?

BULUT: I think where you work as a student or where you do your internship matters a lot.

I think I got this job at ABN because I had worked at the private bank. Because once, the head of the department came to visit the workers there, and he almost never talks to the students. He approached me and said "Hey you were the girl who did an internship at that private bank?" I remember it well, because it is very difficult to get into that place.

After graduation, Bulut wanted to take a break for a couple of months before looking for a job, as she was tired of studying hard and wanted to organize her engagement party. Her fiancée was a descendant of Turkish migrants who was born and raised in Amsterdam and worked as a police officer. Just after the summer, Bulut was approached by a head hunter, who arranged a temporary post for her in the finance department of a corporate firm located close to Amsterdam. She took this opportunity to build work experience, commuting $2 \mathrm{~h}$ every day. Six months later, both Bulut and the company were pleased with her performance, and she was offered a position in one of their branches in Amsterdam. After 2 years, she was offered a permanent contract, which she happily accepted. In the meantime she had also got married and at the time of the second interview she and her husband were considering buying an apartment.

In Strasbourg, Zeynep studied IT management at tertiary vocational school (BTS). Her subject choice had been totally by chance: she decided to try IT because this was the only training which still had space for a new student. She enjoyed the 
course and pursued it further. In contrast to Bulut, Zeynep only had very short internship periods, but they still proved useful for her future transition. Zeynep's father had come to France at a young age, attending school there and developing language skills and cultural capital. He advised Zeynep to go to university rather than entering the labour market. He provided full emotional and financial support for her to access a license professional and Zeynep successfully completed her bachelor's degree course. After graduation, she spent 6 months looking for a job before eventually finding a post in the public sector at one of her former internships. At the time of the interview, she had been working there for over a year. Recently she had been given a permanent position (embouché).

Both Zeynep and Bulut had parents who arrived in the Netherlands and France around the age of 12 and received education in the host countries. Both sets of parents had language capital and information capital about the education system and how the labour market functions. Furthermore, while pursuing the tertiary vocational track, both Zeynep and Bulut were able to conduct internships and develop their own cultural and social capital that facilitated smooth labour market transitions. Bulut's work experience was much more substantial than Zeynep's, and hence her income and contract were also quite prestigious. However, even Zeynep's meagre internship experience proved to be very useful in establishing contacts.

It is also very important to note that all the female respondents in this category expressed a wish to get married, but postponed doing so until they had finished their studies and found employment, in contrast to other respondents who dropped out of education without a degree or gave up on their labour market prospects.

Vocational Track Students' Experiences of Higher Education and Beyond: Prolongation Practice

While for academic students, like Zeynep and Bulut, the decision to pursue higher education was more or less a given, this decision was less straightforward for vocational students, who had to follow a longer trajectory to access higher education. In Amsterdam, prolonging one's education into tertiary education also carries the risk of having to repay the conditional student loan in the event of failure to graduate. This discourages many young people from low income families. Once in possession of a vocational degree, these young people were not only worried about the expense or time involved in studying, but also about missing out on earnings by not entering the labour market (Giroux 1983). In order to prolong their education for another 4 years, they needed various support mechanisms and opportunity structures.

As discussed in the previous section, parental support was even more pivotal for vocational track students. Although their parents were unable to provide practical assistance or give advice on educational choices, they could create the right environment for further study by giving their children emotional or financial support and alleviating their economic concerns about delaying full-time employment that 
would otherwise have formed a solid barrier for them. Serkan's parents exemplified such support, enabling him to extend his studies into tertiary vocational education. Serkan's mother had arrived in the Netherlands at the age of 12, attended vocational school, and become fluent in Dutch. Serkan's father was from his maternal grandparents' village, and together the couple started their own successful dry-cleaning business. Serkan's parents had always been very supportive of their children. Serkan's older brother didn't want to extend his studies: after his vocational degree, he started working in the family business, opening his own branch. Serkan obtained an $\mathrm{MBO}$ degree in sports and physical education. His dream was to become a professional football player. He said that his mother would come to all his games and he always felt he had his parents' backing in all his decisions. However, after a few unfortunate high-risk injuries followed by serious operations, Serkan concluded that there was no future for him in professional football. Then he made a substantial change and decided to attend tertiary vocational education (HBO) in business economics.

SERKAN: I went through two serious operations on my knee. Then I decided that I didn't have a future in football. School is more important for me. You develop yourself and meet different people. When you tell people you are studying at an HBO, they look at you differently. You know, with more respect. I decided to do HBO in business economics. It's more prestigious, you know; when you get a job they give you a car and so on. It's cool.

Serkan not only attributed employment value to tertiary education (Lehmann 2009), but also praised the status and prestige that a higher education diploma brought with it. He already planned on pursuing his studies into university, which is even more reputable. His efforts were welcomed by his parents. Serkan emphasized that he had a part-time job as a gym instructor and paid for his own study costs. However, he also mentioned that his father was ready to pay for anything as long as he was willing to study. Even though his parents could not help Serkan with his course or studies, they still created a supportive environment for him.

Not all the students in Amsterdam who accessed higher education training managed to complete their studies or felt supported to the same extent. Financial support from one's family was a crucial dynamic in Amsterdam, as the obligation to repay the student loan if one dropped out of tertiary vocational education was a major deterrent. The risk of failure was exacerbated by the fear of incurring a debt after one had delayed full-time employment. These obstacles mean that vocational track students need to have dedication, a clear goal and be resilient. In Amsterdam, Emre was among the students who experienced cyclical periods of employment, training and unemployment. He had already embarked on three different HBO courses, but hadn't completed any of them. He had an MBO diploma in trading and sales, but didn't enjoy working in that field. He said that, during his internships, he had not worked in the area of his studies, but had counted his work in a supermarket as internships. Consequently, he had no idea of what awaited him on the labour market. As a result, he ended up working mostly in low-skilled jobs at the airport or in supermarkets, or trying new training courses. 
In Strasbourg, financial obligations and lack of parental support made it particularly difficult for students to access higher education as combining work and study was not a feasible option. Behzat's case was discussed in the previous chapter. After attaining his vocational degree, he first went to the professional lyceum and then accessed vocational tertiary education. Being forced to work while studying led him to drop out. Behzat's father had arrived in Strasbourg as a guest worker. He had little education and worked in factories until his retirement. Behzat was the family's youngest child, and his parents were already retired by the time he went to school. His father was not very supportive of his decision to undertake further study. On the contrary, Behzat felt that he was expected to start working full time as soon as possible, but as he wanted to study further, he decided to take a part-time job. This became too demanding and eventually he dropped out of school and started doing factory work full-time. During the interview, Behzat was quite regretful and angry about dropping out because after quitting BTS, he had managed to find a job through his internship, even though he did not have a BTS diploma. Despite having a permanent contract, Behzat was afraid that if the factory closed down he would not be able to find another job at BTS level.

Another important factor that affected whether or not respondents accessed higher education was taking a risk-averse strategy, as is illustrated by Şebnem's story. Previous studies have examined risk averse behaviour regarding higher education, especially among female descendants of immigrants from Turkey (Pasztor 2009). However, this type of risk aversion was different from the ones applied in most studies (Van De Werfhorst and Hofstede 2007); my respondents were not avoiding downward mobility as they had already achieved upward social mobility compared to their parents. However, they took a guaranteed or instrumental approach. Most respondents chose easier pathways to avoid the risk of failure, and considered it easier to 'fall back on' a vocational degree in the event of failure. Şebnem had immigrant parents with a low education level. After school, she decided to attend a vocational college, despite her above average grades, as she preferred to start work rather than go to university and thought that a vocational degree would be sufficient. Her experience in vocational training was rewarding, and, together with her best friend, who was from a similar background, she was advised by her teachers to attend professional lyceum. Working with her peer proved to be a successful strategy for Şebnem, as it is for many other children of immigrants (Crul 1999, 2000). Once they graduated from professional lyceum, they both decided to attend university. Şebnem was determined to stay low profile so chose a subject (sociology), which was accessible but also easy to succeed at.

At university, Şebnem met her husband. A law student, he was also the child of Turkish immigrants. They decided to get married in their second year and Şebnem moved in with her husband's mother. She started working part time in childcare centres alongside her studies in order to contribute to the family income. One year later, she had her first child. She mentioned that living with her husband's mother had been very helpful, as her mother-in-law would take care of the child and do 
most of the household tasks. Şebnem managed to get her bachelor degree with a 2 -year delay, together with additional training in child care (formation). Hence she managed to study, work and start a family, all at the same time. She accumulated significant experience in the education sector, and found a job in a mixed school as a manager dealing with parents and children with a migrant background. Şebnem mentions that she never had high ambitions about higher education, but had just made sure that she obtained all the diplomas as she climbed the ladder. Şebnem's case is not only an example of an extended educational career, but also shows the complexities of today's transitions. She managed to combine her studies with work, marriage and child rearing.

However, in doing so, she relied heavily on family support. These resources are reminiscent of the forms of gendered capital discovered by Skeggs (2004a) among working-class mothers. Many mothers' altruistic behaviour has facilitated a successful transition for the female descendants of immigrants. This is a distinct form of family support, whereby parents provide assistance in dealing with the difficulties of married life, domestic responsibilities and combining work with studies. Thus marriage continues to be a valid cohabitation practice for native-born descendants of immigrants from Turkey, and is not necessarily an alternative to working or education if the extended family is willing and able to facilitate distinct combinations of all these activities.

\subsection{Conclusion: Gendered Pathways and the Role of Family Support}

Previous studies have argued that, in today's societies, youth transitions are becoming more extended, fragmented and complex. In this chapter, I illustrate the struggles of the native-born descendants of immigrants from Turkey in Amsterdam and Strasbourg during their transition from school to various forms of adulthood. In doing so I have tried to show that the prolonged nature of transitions, whose newness is also debated (see Coté and Bynner 2008) cannot be taken for granted and that young people face financial pressures and structures that either impede or enhance the opportunities available to them during their transition pathways.

The study's comparative design uncovers structural similarities and differences between Amsterdam and Strasbourg. First of all, young people's capacity to continue their studies into higher education was strongly influenced by their initial tracking: academic track students were more likely to extend their studies into tertiary education in both cities. However the perceived value of (higher education) qualifications were pivotal in working class youths' educational decisions (Lehmann 2007). Confirming Lehmann's argument, my interviewees' decisions to enter higher education were informed by their perceptions of whether the benefits of higher educational degrees would outweigh the cost of delaying entry to the labour market, 
by up to 4 years. In Amsterdam the decision to continue on to tertiary education was more straightforward than in Strasbourg, where doubts about the value of additional qualifications often caused students avoid such a course of action. This led many of my interviewees in France to drop out of education after receiving their lyceum diploma. This finding is backed up by quantitative data from the TIES survey (date) which shows that $21 \%$ of descendants of migrants in Strasbourg left education with a lyceum diploma, compared to 5\% in Amsterdam (See Tables 4.1 and 4.2). This emphasizes the educational decisions of people with very similar resources and backgrounds are strongly conditioned by structural features, which have a profound effect on these people's transition pathways and outcomes.

In both settings parental support was critical in assisting transition decisions. All of the respondents of this study in both settings originated from lower-class families. None of the parents were able to provide instrumental support such as advising on educational decisions or career choice or helping with course work (Rezai et al. 2015). Nevertheless parental support mechanisms (Jones 2009) were crucial, even when they do not take the form of middle-class knowledge of how the educational and employment systems work (or possessing social capital within them). Economic capital was especially crucial in creating a comfort zone that allowed young people to extend their studies without worrying about earning an income. Emotional capital and practical help from parents in sharing daily responsibilities also helped respondents achieve a complex transition. Skeggs (2004b) has highlighted the importance of the forms of capital possessed by working-class mothers, which do not, in Bourdieu's terms have an exchange value. Reay (2004) also refers to this as emotional capital and show that it and can still provide great advantage. The arguments of Skeggs (2004b) and Reay (2004) were confirmed by my data; immigrant parents are able to provide emotional capital, which can prove very effective. In fact lack of such support made it virtually impossible for descendants of migrants to prolong their transitions successfully.

The lack of instrumental support or absence of social capital provided by parents increased the importance of another institutional structure: internship and educationrelated work experiences. Unable to access crucial work contacts through their parents, descendants of migrants relied heavily on the contacts and skills built during their internships. A successful internship experience led to both the development of competences and cultural capital about employment practices, and also generated social capital, which was vital in accessing jobs. This was more the case in Amsterdam than in Strasbourg since vocational and tertiary vocational education in the Netherlands require extended internship periods. However this also implied that a lack of such internship experience had more negative consequences for young people in Amsterdam. In Amsterdam, vocational track students who were not able to benefit from an instrumental internship experience-or, even worse, who dropped out of the vocational track without a diploma-had limited options such as lowskilled service jobs or labour-intensive employment, as we have seen with the profiles of early school leavers. While some of these young people repeatedly became unemployed, others built cultural capital through their work experience, establishing weak ties to find their way back into career tracks. In France, the lack of internship 
experience among vocational students did not result in much deviation: respondents with or without a vocational diploma ended up in low-skilled employment in manufacturing or the service sector. Young people working in these jobs worked under demanding conditions, relied heavily on employment agencies which contracted them to temporary arrangements, eventually making it difficult to achieve stability.

For academic track students in both settings, employment practices in the area of their studies proved to be instrumental in developing different forms of capital, especially social capital. In fact, highly-educated respondents almost exclusively relied on the social capital that they had developed themselves throughout their studies or internships or work experience. This could provide an explanation for the high unemployment rates among higher education graduates in Amsterdam (Hoger Onderwijs Bureau 2015). A lack of relevant internship experience where they can build resources leaves descendants of migrants without assistance in their transitions to work.

Finally, another interesting finding from this detailed study of transitions is marriage as an alternative transition pathway, especially voiced and applied among female respondents. The prevalence of marriage at an early age among descendants of migrants existed in parallel to other transition practices and added to the complexity of the picture. Marriage continues to be the most acceptable and common form of cohabitation and child-rearing for both the male and female native-born descendants of immigrants from Turkey in Europe (Milewski and Hamel 2010). However marriage as a transition pathway has been widely ignored in transition studies, due to changing practices among the general population (Willoughby et al. 2015). Yet, especially for female descendants of migrants who fail at school or despair of finding a job, marriage provided an alternative transition pathway. This adds to the complexity of their transitions as some manage to combine marriage and children with school and part-time work with the help of parents or extended family. As a result this chapter did document prolonged and complex youth transitions among Turkish descendants of immigrants yet the conditions and consequences of this complexity and prolongation varied across institutional settings and depended heavily on the resources of young people circumscribed by the individuals' social class, gender and ethnicity.

\section{References}

Andersen, R., \& Van de Werfhorst, H. G. (2010). Education and occupational status in 14 countries: The role of educational institutions and labour market coordination. The British Journal of Sociology, 61, 336-355.

Blossfeld, H. P. (2008). Young workers, globalization and the labor market: Comparing early working life in eleven countries. Cheltenham: Edward Elgar Publishing.

Bol, T., \& Van de Werfhorst, H. G. (2013). Educational systems and the trade-off between labor market allocation and equality of educational opportunity. Comparative Education Review, 57(2), 285-308. 
Brinbaum, Y., \& Guégnard, C. (2011). De l'orientation au sentiment de discrimination: Parcours de formation et d'insertion des jeunes issus de l'immigration. [Orientations towards feelings of discrimination: Education and transition pathways of young people with migration background]. Net.Doc 78, Cereq, Marseille.

Brinbaum, Y., \& Guégnard, C. (2013). Choices and enrollments in French secondary and higher education: Repercussions for second-generation immigrants. Comparative Education Review, 57(3), 481-502.

Brown, P. (1987). Schooling ordinary kids: Inequality, unemployment, and the new vocationalism. London: Tavistock Books.

CBS. (2012). Turkse Ingezetenen in Nederland 2011. Den Haag: Centraal Bureau Voor Statistics.

Côté, J., \& Bynner, J. M. (2008). Changes in the transition to adulthood in the UK and Canada: The role of structure and agency in emerging adulthood. Journal of Youth Studies, 11(3), 251-268.

Crul, M. (1999). Explanations for success among second-generation Moroccan and Turkish youth in the Netherlands: A theory of practice. Amsterdam: Het Spinhuis.

Crul, M. (2000). Breaking the circle of disadvantage: Social mobility of second-generation Moroccans and Turks in the Netherlands. In H. Vermeulen \& J. Perlmann (Eds.), Immigrants, schooling, and social mobility: Does culture make a difference? (pp. 225-244). Houndmills/ Basingstoke/Hampshire/New York: Macmillan Press.

De Vries, M. R., \& Wolbers, M. H. J. (2005). Non-standard employment relations and wages among school leavers in the Netherlands. Work, Employment \& Society, 19(3), 503-525.

Delsen, L., \& Poutsma, E. (2005). Labour market institutions and economic performance in the Netherlands. International Economic Journal, 19(2), 169-196.

Duru-Bellat, M. (2000). Social inequalities in the French education system: The joint effect of individual and contextual factors. Journal of Educational Policy, 15(1), 33-40.

Duru-Bellat, M., \& Kieffer, A. (2008). From the Baccalauréat to higher education in France: Shifting inequalities. Population, 63(1), 119-154.

Eckert, H. (2005). Les «Bac Pro» À L'usine, Ou Le Travail Du Désenchantement. Recherches, 289-299.

Eurostat. (2010). Key indicators for core cities. European Commission. Available at: Http:// Eppeurostat.Ec.Europa.Eu/Portal/Page/Portal/Region_Cities/City_Urban/Data_Cities/ Databasa_Sub1

Furlong, A. (2009). Handbook of youth and young adulthood. New perspectives and agendas. London: Routledge.

Furlong, A., \& Cartmel, F. (1997). Young people and social change individualization and risk in late modernity. Buckingham: Open University Press.

Gaskell, J. (1992). Gender matters from school to work. Toronto: Oise Press.

Giroux, H. A. (1983). Theories of reproduction and resistance in the new sociology of education: A critical analysis. Harvard Educational Review, 53(3), 257-293.

Granovetter, M. (2005). The impact of social structure on economic outcomes. The Journal of Economic Perspectives, 19(1), 33-50.

Hannan, D. F., Raffe, D., \& Smyth, E. (1997). Cross-national research on school to work transitions: An analytical framework. Background paper prepared for the planning meeting for the thematic review of the transition from initial education to working life.

Hargreaves, A. G. (2007). Multi-ethnic France immigration, politics, culture and society. New York/London: Routledge.

Hoger Onderwijs Bureau. (2015, July 13). Allochtone hbo'ers komen moeilijk aan de bak. Retrieved from https://punt.avans.nl/2015/07/allochtone-hboers-komen-moeilijk-aan-de-bak/

Iannelli, C., \& Raffe, D. (2007). Vocational upper-secondary education and the transition from school. European Sociological Review, 23(1), 49-63.

Jones, G. (2009). From paradigm to paradox: Parental support and transitions to independence. In I. Schoon \& R. K. Silbereisen (Eds.), Transitions from school to work: Globalization, individualization, and patterns of diversity (pp. 145-164). New York: Cambridge University Press. 
Kalmijn, M., \& Kraaykamp, G. (2003). Dropout and downward mobility in the educational career: An event-history anaylsis of ethnic schooling differences in the Netherlands. Educational Research and Evaluation, 9(3), 265-287.

Kloosterman, R., \& Rath, J. (2001). Immigrant entrepreneurs in advanced economies: Mixed embeddedness further explored. Journal of Ethnic and Migration Studies, 27(2), 189-201.

Lehmann, W. (2004). 'For some reason, I get a little scared': Structure, agency, and risk in schoolwork transitions. Journal of Youth Studies, 7(4), 379-396.

Lehmann, W. (2007). Choosing to labour? School-to-work transitions and social class. Ithaca: Mcgill-Queen's University Press.

Lehmann, W. (2009). University as vocational education: Working-class students' expectations for university. British Journal of Sociology of Education, 30(2), 137-149.

Longwell-Grice, R. (2003). Get a job: Working class students discuss the purpose of college. College Student Affairs Journal, 23(1), 40.

Macleod, J. (2009). Ain't no Makin' it. Boulder: Westview Press.

Maurice, M., Sellier, F., \& Silvestre, J. J. (1986). The social foundations of industrial power: A comparison of France and Germany. Cambridge: MIT Press.

Mellottee, L., Becquet, V., Danic, I., Lepape, M.-C., Leroy, P., Loncle, P., \& Muniglia, V. (2010). Country report: France governance of educational trajectories in Europe. Amsterdam: University of Amsterdam.

Meurs, D., Ariane Pailhé And Patrick Simon (2005). "Mobilité Intergénérationnelle Et Persistance Des Inegalites: L'acces À L'emploi Des Immigres Et De Leurs Descendants En France.” Paris: Ermes.

Milewski, N., \& Hamel, C. (2010). Union formation and partner choice in a transnational context: The case of descendants of Turkish immigrants in France. International Migration Review, 44(3), 615-658.

Mueller, W., \& Gangl, M. (Eds.). (2003). Transitions from education to work in Europe: The integration of youth into EU labour markets. Oxford: England University Press.

Nell, L., \& Rath, J. (2009). Am I Amsterdam? Immigrant integration and urban change. In L. Nell \& J. Rath (Eds.), Ethnic Amsterdam: Immigrants and urban change in the twentieth century (pp. 11-23). Amsterdam: Amsterdam University Press.

Pasztor, A. (2009). Different settings, different choosers? Applying Ball's framework on the case of second generation Turks. International Studies in Sociology of Education, 19, 203-215.

Pasztor, A. (2010). Imagined futures: Why business studies dominate the higher education choices of second-generation Turks in the Netherlands? Ethnic and Racial Studies, 35, 704-717.

Powell, J. J., Coutrot, L., Graf, L., Bernhard, N., Kieffer, A., \& Solga, H. (2009). Comparing the relationship between vocational and higher education in Germany and France (No. SP I 2009506). WZB Discussion Paper.

Raffe, D. (2003). Pathways linking education and work: A review of concepts, research, and policy debates. Journal of Youth Studies, 6(1), 3-19.

Rath, J. (2002). A quintessential immigrant niche? The non-case of immigrants in the Dutch construction industry. Entrepreneurship \& Regional Development, 14(4), 355-372.

Reay, D. (2004). Gendering Bourdieu's concepts of capitals? Emotional capital, women and social class. The Sociological Review, 52(s2), 57-74.

Remery, C., van Doorne-Huiskes, A., \& Schippers, J. (2002). Labour market flexibility in the Netherlands: Looking for winners and losers. Work, Employment and Society, 16(3), 477-495.

Rezai, S., Crul, M., Severiens, S., \& Keskiner, E. (2015). Passing the torch to a new generation: A qualitative study of the highly educated second generation's receiving of parental support and giving of support to the younger generation. Journal of Comparative Migration Studies, 3, 12.

Skeggs, B. (2004a). Class, self culture. London: Routledge.

Skeggs, B. (2004b). Exchange, value and affect: Bourdieu and 'the self'. The Sociological Review, 52(2_suppl), 75-95.

Tesser, P., \& Dronkers, J. (2007). Equal opportunities or social closure in the Netherlands. Proceedings of British Academy, 136, 359-401. 
Van De Werfhorst, H. G., \& Hofstede, S. (2007). Cultural capital or risk aversion? Two mechanisms for educational inequality compared. British Journal of Sociology, 58(3), 391-415.

Van der Velden, R. K., \& Wolbers, M. H. (2006). How much does education matter and why? The effects of education on socio-economic outcomes among school-leavers in the Netherlands. European Sociological Review, 23(1), 65-80.

Willis, P. E. (1977). Learning to labor: How working class kids get working class jobs. Farnborough: Saxon House.

Willoughby, B. J., Hall, S. S., \& Luczak, H. P. (2015). Marital paradigms: A conceptual framework for marital attitudes, values, and beliefs. Journal of Family Issues, 36(2), 188-211.

Wolbers, M. H. (2003). Combinaties van werken en leren onder jongeren in Europa. Tijdschrift voor Arbeidsvraagstukken, 19(1), 20-33.

Wolbers, M. H. J. (2008). Increasing labor market instability among young people? Labor market entry and early career development among school-leavers in the Netherlands since the mid1980s. In H. Blossfeld (Ed.), Young workers, globalization and the labor market: Comparing early working life in eleven countries (pp. 77-101). Cheltenham: Edward Elgar Publishing.

Wolbers, M. H., De Graaf, P. M., \& Ultee, W. C. (2001). Trends in the occupational returns to educational credentials in the Dutch labor market: Changes in structures and in the association? Acta Sociologica, 44(1), 5-19.

Wyn, J., \& Dwyer, P. (1999). New directions in research on youth in transition. Journal of Youth Studies, 2(1), 5-21.

Zdrojewski, S. (2011). Ethnic disadvantages at labor market entry in France? In H. P. Blossfeld \& D. Hofäcker (Eds.), Youth on globalised labour markets: Rising uncertainty and its effects on early employment and family lives in Europe (pp. 121-162). Opladen/Farmington Hills: Barbara Budrich Publishers.

Zdrojewski, S., Grelet, Y., \& Vallet, L.-A. (2008). Increasing employment instability in France? Young people's labor market entry and early career since the 1990s. In H. Blossfeld (Ed.), Young workers, globalization and the labor market: Comparing early working life in eleven countries (pp. 103-127). Cheltenham: Edward Elgar Publishing.

Open Access This chapter is licensed under the terms of the Creative Commons Attribution 4.0 International License (http://creativecommons.org/licenses/by/4.0/), which permits use, sharing, adaptation, distribution and reproduction in any medium or format, as long as you give appropriate credit to the original author(s) and the source, provide a link to the Creative Commons licence and indicate if changes were made.

The images or other third party material in this chapter are included in the chapter's Creative Commons licence, unless indicated otherwise in a credit line to the material. If material is not included in the chapter's Creative Commons licence and your intended use is not permitted by statutory regulation or exceeds the permitted use, you will need to obtain permission directly from the copyright holder.

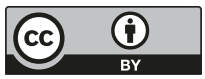

